\title{
ECOLOGICAL AND ECONOMIC IMPORTANCE OF IBAJAY MANGROVE ECO-TOURISM PARK
}

\author{
Ricky B. Acanto 1 \\ ${ }^{1}$ School of Arts and Sciences, Carlos Hilado Memorial State College, Talisay City, Negros Occidental, Philippines \\ acantoricky@gmail.com/ricky_acanto@yahoo.com
}

\begin{abstract}
The study sought to determine the ecological and economic importance of Ibajay Mangrove Eco-Tourism Park, the willingness to pay and the average amount the respondents are willing to pay for the entrance fee and conservation fee of the eco-tourism park. The study utilized the researcher-made questionnaire and purposive sampling technique. The respondents of the study were composed of one hundred sixty (160) visitors of the eco-tourism park, namely: businessmen, educators, industrial partners, Local Government Unit personnel, researcher, residents, students, and tourists (Local, National, international). Frequency count and percentage were used to analyze the data gathered; and computation of the average amount for the willingness to pay of the respondents. The result revealed that $95 \%$ of the respondents are aware of the ecological and economic importance of Ibajay Mangrove Eco-Tourism Park and only 5\% are not aware of its importance. Maintaining the ecological balance of nature topped among the ecological importance with $95.6 \%$ followed by it served as foraging and living places for wildlife with $67.5 \%$. For the economic importance, $74.4 \%$ of the respondents agreed that the eco-tourism park both brings financial incentives to the community and served as sightseeing route for eco-tours. Eighty point sixty-six (80.66\%) percent of the respondents are willing to pay for the entrance fee and $95.6 \%$ are willing to pay for the conservation of the eco-tourism park. The respondents are willing to pay for an average of $P 38.75$ per visit and are willing to pay for an average of $P 116.88$ per month for the conservation of the eco-tourism park. The average amount which is $P 38.75$ is higher than P 20.00, the present entrance fee of the eco-tourism park. Among the respondents, businessmen are willing to pay higher for an average of $P 75.00$ for the entrance fee and industrial partners are willing to pay as much as $P 142.00$ per month for the conservation fee.
\end{abstract}

Keywords: Awareness, Eco-Tourism, Economic Value, Mangroves, Willingness To Pay.

\section{INTRODUCTION}

The mangrove forests form one of the world's most extraordinary ecosystem that are most productive and biodiverse but are under threat. Ecological and economic benefits can be obtained in mangrove forests. Mangrove ecosystem serves as nursery grounds for numerous fish and shellfish, it prevents the soil from being washed away and known to stabilize the coastal areas. Furthermore, the mangrove forest serves as a source of important products to coastal communities in the form of charcoal, firewood, food, timber and other livelihood activities.

In recent years, ecotourism activities like the mangrove ecopark are increasing due to its ecological, economic and socio-cultural values. It created sources of sustainable income to local community and creating awareness of the services and benefits provided by mangroves.

With the changing lifestyles, economy and climate, there have been changes in the attitude and perception of people toward eco-tourism. There have been increased in the environmental awareness both from the rural and urban people. People are now looking for a new get away locations, where they could get involved in the active outdoor recreations. Thus, national parks and sanctuaries have emerged as the favorite destinations. In consonance, the Municipality of Ibajay developed an Ibajay Mangrove
Eco-Tourism Park as nature's sanctuary located at Brgy. Bugtongbato and Brgy. Naisud.

Ibajay Mangrove Eco-Tourism Park is 44 hectares of mangroves and the only mangroves community in the country with a total of 28 species or 80 percent of the total of 35 Philippine species [17]. The eco-tourism park has 800$\mathrm{m}$ stretch of footbridge and has the centuries-old mangrove trees, Avicennia rumphiana, locally known as api-api or bungalon. The preserved number of species of mangroves is one of the reasons why the place is often visited by locals as well as international tourists and environmentalists.

Assessment of mangrove eco-tourism park's ecological and economic value is of great help to improve the understanding of mangroves and heighten public awareness of the importance of mangrove ecosystem as a whole [11].

The ecological and economic value of Ibajay Eco-Tourism Park is important to the academe and community in the vicinity of the eco-tourism park. The study sought to investigate and solicit the community's participation in the promotion and conservation of Eco-Tourism Park's mangrove forests for sustaining the livelihood of the community. It is also for this reason that the researcher sought to establish baseline data in terms of visitor's willingness to pay to various eco-tourism parks' services. 


\subsection{Statement of the Problem}

Generally, the study aimed to determine the ecological and economic value of Ibajay Mangrove Eco-Tourism Park, Ibajay, Aklan, Philippines.

Specifically, the study sought to:

1. Determine the respondents' awareness in terms of ecological and economic importance of eco-tourism park.

2. Determine the ecological importance of the eco-tourism park.

3. Determine the economic importance of the eco-tourism park.

4. Determine the willingness to pay of the respondents for the entrance fee and conservation to the eco-tourism park.

5. Determine the average amount the respondents are willing to pay for the entrance fee and conservation of the eco-tourism park.

\subsection{Significance of the Study}

Article III, Section 45 (Disposition of Public Lands for Fishery Purpose) of Republic Act 8550 otherwise known as the Philippine Fisheries Code of 1998 stated that public lands such as tidal swamps, mangroves, marshes, foreshore lands and ponds suitable for fishery operations shall not be disposed or alienated. Furthermore, Chapter VI, Section 94 concerned about Prohibition and Penalties on Conversion of Mangroves states that it shall be unlawful for any reason to convert mangroves into fishponds or any other purposes. Violation of this section is punishable by six to twelve years of imprisonment and a fine of P80, $000.00 \mathrm{and} /$ or if the area requires rehabilitation or restoration as determined by the court, the offender should be required to restore or compensate for restoration of the damage [23].

Mangroves contribute to mitigating the effects of climate change. Mangroves roots collect sediments and slow water flows thus, protecting the coastlines from erosion. Overtime these collected sediments, mud and debris allow the plant to keep up with the rising sea level and extend the coastline further out [24].

\section{METHODOLOGY}

\subsection{Area of the Study}

The Ibajay Mangrove Eco-Tourism Park is situated between Brgy. Bugtong Bato and Naisud, Ibajay, Aklan, Philippines. It covers 72-ha patch of mangroves inhabited by 27 out of 33 species found in the island of Panay which recognized by the SEAFDEC Aquaculture Department. In addition to the natural components of the park, there are also tree houses, friendship-bridge and other facilities for tourists.

\subsection{Respondents of the Study}

The respondents of the study were composed of one hundred sixty (160) visitors of the eco-tourism park, namely: businessmen, educators, industrial partners, Local Government Unit personnel, researcher, residents, students, and tourists (Local, National, international).
Table - 1. Distribution of Respondents

\begin{tabular}{|c|c|c|}
\hline Respondents & $\mathrm{f}$ & $\%$ \\
\hline Businessmen & 20 & $12.5 \%$ \\
\hline Educators & 20 & $12.5 \%$ \\
\hline Industrial Partners & 20 & $12.5 \%$ \\
\hline LGU Personnel & 20 & $12.5 \%$ \\
\hline Researchers & 20 & $12.5 \%$ \\
\hline Residents & 20 & $12.5 \%$ \\
\hline Students & 20 & $12.5 \%$ \\
\hline $\begin{array}{ll}\text { Tourists } \\
\begin{aligned} \text { a. } & \text { Local } \\
\text { b. } & \text { National } \\
\text { c. } & \text { International }\end{aligned}\end{array}$ & $\left.\begin{array}{ll}\text { a. } & 14 \\
\text { b. } & 4 \\
\text { c. } & 2\end{array}\right\} 20$ & $12.5 \%$ \\
\hline Total & 160 & $100 \%$ \\
\hline
\end{tabular}

\subsection{Data Gathering Instruments}

Researcher-made questionnaire was used to gather respondents' information needed in the study. A combination of open-ended and dichotomy type of questions are utilized. The researcher personally administered the questionnaire to the respondents. The prepared questionnaire was validated using the Eight Point Criteria of validation. Willingness-to-pay (WTP) was used in the study which involves direct asking the respondents of the maximum amount they are willing to pay for the entrance fee and conservation of the park.

\subsection{Statistical Analysis}

Frequency count. The frequency count was used to find out the number of the responses to each item in the questionnaire and also the number of respondents in each category in the study.

Percentage. Percentage with reference to the majority criterion will be used to describe the ecological and economic value of Ibajay Mangrove Eco-Tourism Park. Majority criterion refers to any number that is more than one-half of totals. This means $50 \%$ plus one.

Computation of the average amount for the willingness to pay of the respondent for the entrance fee and conservation of the eco-tourism park.

\section{RESULT AND DISCUSSION}

Table 2 shows that 152 out of 160 respondents or $95 \%$ are aware of the ecological and economic importance of Ibajay Mangrove Eco-Tourism Park and only 8 or 5\% are not aware of its importance. Mangroves are now given importance by the scientific communities and local government units for its ecological and economic values to mankind. As stated by [11], communities in tsunami affected areas in Thailand have recognized the ecological and economic importance of mangroves ecosystem to their lives and livelihood which help them uplift their standard of living. Likewise, the ecological and economic literature of mangrove ecosystems in Karachi Coastal areas has brought significant ecological and economic values which contribute to the local economy. 
Table - 2. Distribution of Responses on Awareness of Ecological and Economic Importance of Ibajay Mangrove Eco-Tourism Park

\begin{tabular}{|l|c|c|c|c|}
\hline \multirow{2}{*}{\multicolumn{1}{|c|}{ Respondents }} & \multicolumn{2}{c|}{ Yes } & \multicolumn{2}{c|}{ No } \\
\cline { 2 - 5 } & $\mathrm{f}$ & $\%$ & $\mathrm{f}$ & $\%$ \\
\hline Businessmen & 16 & 10.00 & 4 & 2.50 \\
\hline Educators & 18 & 11.25 & 2 & 1.25 \\
\hline Industrial Partners & 20 & 12.50 & 0 & 0 \\
\hline LGU Personnel & 20 & 12.50 & 0 & 0 \\
\hline Researchers & 20 & 12.50 & 0 & 0 \\
\hline Residents & 20 & 12.50 & 0 & 0 \\
\hline Students & 20 & 12.50 & 0 & 0 \\
\hline Tourists & 18 & 11.25 & 2 & 1.25 \\
\hline Total & 152 & $\mathbf{9 5 \%}$ & 8 & $\mathbf{5 \%}$ \\
\hline
\end{tabular}

Table 3 shows the ecological importance of mangroves ecosystem to the respondents. 153 or $95.6 \%$ of the respondents agreed that maintaining the ecological balance of nature topped among the ecological importance of the eco-tourism park. Mangroves are ecologically important in maintaining and building the soil and as a reservoir in the tertiary assimilation of waste Mangroves trap sediments and so contribute to land building, preventing erosion and excessive shifting of coastlines [25].

Moreover, 108 or $67.5 \%$ respondents agreed that the ecotourism park served as a foraging and living places for wildlife. Mangrove ecosystems are among the most productive ecosystems that directly or indirectly provide ecological and economic benefits to human. It provides a unique habitat for animals, breeding ground for unique species of flora and fauna [5].

Table - 3. Distribution of Responses on Ecological Importance of Ibajay Mangrove Eco-Tourism Park

\begin{tabular}{|c|c|c|c|c|c|c|c|c|c|c|c|c|c|c|}
\hline \multirow{3}{*}{ Respondents } & \multicolumn{14}{|c|}{ Ecological Value of Ibajay Mangrove Eco-Tourism Park } \\
\hline & \multicolumn{2}{|c|}{$\begin{array}{l}\text { Foraging } \\
\text { and Living } \\
\text { places for } \\
\text { wildlife }\end{array}$} & \multicolumn{2}{|c|}{$\begin{array}{l}\text { Venue for } \\
\text { spiritual } \\
\text { activities }\end{array}$} & \multicolumn{2}{|c|}{$\begin{array}{l}\text { Venue for } \\
\text { school } \\
\text { activities }\end{array}$} & \multicolumn{2}{|c|}{$\begin{array}{l}\text { Recreational } \\
\text { undertakings }\end{array}$} & \multicolumn{2}{|c|}{$\begin{array}{c}\text { Interactive } \\
\text { classroom } \\
\text { for outdoor } \\
\text { teaching }\end{array}$} & \multicolumn{2}{|c|}{$\begin{array}{c}\text { Maintain } \\
\text { ecological } \\
\text { balance of } \\
\text { nature }\end{array}$} & \multicolumn{2}{|c|}{ Others } \\
\hline & $\mathrm{f}$ & $\%$ & $\mathrm{f}$ & $\%$ & f & $\%$ & f & $\%$ & $\mathrm{f}$ & $\%$ & f & $\%$ & $f$ & $\%$ \\
\hline Businessmen & 8 & 5.0 & 1 & 0.6 & 4 & 2.5 & 14 & 8.8 & 5 & 3.1 & 19 & 11.9 & 0 & 0.0 \\
\hline Educators & 11 & 6.9 & 3 & 1.9 & 2 & 1.3 & 7 & 4.4 & 5 & 3.1 & 16 & 10.0 & 0 & 0.0 \\
\hline Industrial Partners & 14 & 8.8 & 0 & 0.0 & 14 & 9.4 & 16 & 10.6 & 14 & 8.8 & 20 & 12.5 & 0 & 0.0 \\
\hline LGU Personnel & 14 & 8.8 & 1 & 0.6 & 10 & 6.3 & 18 & 11.3 & 14 & 8.8 & 20 & 12.5 & 0 & 0.0 \\
\hline Researchers & 17 & 10.6 & 1 & 0.6 & 5 & 3.1 & 16 & 10.0 & 18 & 11.3 & 20 & 12.5 & 0 & 0.0 \\
\hline Residents & 11 & 6.9 & 3 & 1.9 & 4 & 2.5 & 3 & 1.9 & 6 & 3.8 & 20 & 12.5 & 0 & 0.0 \\
\hline Tourists & 18 & 11.3 & 3 & 1.9 & 6 & 3.8 & 7 & 4.4 & 9 & 5.6 & 18 & 11.3 & 0 & 0.0 \\
\hline Students & 15 & 9.4 & 4 & 2.5 & 6 & 3.8 & 7 & 4.4 & 12 & 7.5 & 20 & 12.5 & 0 & 0.0 \\
\hline Total & 108 & 67.5 & 16 & 10.0 & 52 & 32.5 & 88 & 55 & 83 & 51.9 & 153 & 95.6 & $\overline{0}$ & $\overline{0.0}$ \\
\hline
\end{tabular}

Table 4 shows that in terms of the economic importance, 119 out of 160 or $74.4 \%$ of respondents identified that the Ibajay Mangrove Eco-Tourism Park both brings financial incentives to the community and served as sightseeing route of eco-tours. Ibajay communities are slowly reaping the benefits both Peoples Organization (BugtongBato Fisherfolk Association and Naisud Mangrove Aquatic Organization) shares $80 \%$ of the total net income generated from the ecotourism park. In addition, Ibajay is becoming an alternative tour destination with the help of the Department of Tourism [25]. Ecotourism activities are increasing, providing further sources of sustainable income to local communities and creating awareness of services and benefits provided by mangroves.
On the other hand, only 88 or $55.0 \%$ of the respondents believed that Ibajay Mangrove Eco-Tourism Park could be a source of raw materials. Local communities benefited economically from the raw materials obtained from the area like nipa, firewood, and utilization of nipa fruit as fillings. The value of mangrove ecosystems in supporting local economic production are substantial and can contribute in achieving a better development outcomes for the coastal communities while maintaining global values [9]. 
Table - 4. Distribution of Responses on Economic Importance of Ibajay Mangrove Eco-Tourism Park.

\begin{tabular}{|c|c|c|c|c|c|c|c|c|c|c|c|c|}
\hline \multirow{3}{*}{ Respondents } & \multicolumn{12}{|c|}{ Economic Value of Ibajay Mangrove Eco-Tourism Park } \\
\hline & \multicolumn{2}{|c|}{$\begin{array}{l}\text { Source of Food } \\
\text { Resources }\end{array}$} & \multicolumn{2}{|c|}{$\begin{array}{l}\text { Source of Raw } \\
\text { Materials }\end{array}$} & \multicolumn{2}{|c|}{$\begin{array}{l}\text { Source of } \\
\text { Livelihood }\end{array}$} & \multicolumn{2}{|c|}{$\begin{array}{l}\text { Sightseeing } \\
\text { route of eco- } \\
\text { tours }\end{array}$} & \multicolumn{2}{|c|}{$\begin{array}{l}\text { Brings } \\
\text { financial } \\
\text { incentives to } \\
\text { the } \\
\text { community }\end{array}$} & \multicolumn{2}{|c|}{ Others } \\
\hline & $\mathrm{f}$ & $\%$ & $\mathrm{f}$ & $\%$ & $\mathrm{f}$ & $\%$ & $\mathrm{f}$ & $\%$ & $\mathrm{f}$ & $\%$ & $\mathrm{f}$ & $\%$ \\
\hline Businessmen & 9 & 5.6 & 11 & 6.9 & 13 & 8.1 & 15 & 9.4 & 20 & 12.5 & 0 & 0.0 \\
\hline Educators & 3 & 1.9 & 3 & 1.9 & 7 & 4.4 & 15 & 9.4 & 7 & 4.4 & 0 & 0.0 \\
\hline Industrial Partners & 17 & 10.6 & 16 & 10.0 & 18 & 11.3 & 20 & 12.5 & 20 & 12.5 & 0 & 0.0 \\
\hline LGU Personnel & 15 & 9.4 & 15 & 9.4 & 16 & 10.0 & 18 & 11.3 & 15 & 9.4 & 0 & 0.0 \\
\hline Researchers & 13 & 7.5 & 15 & 9.4 & 16 & 10.0 & 14 & 8.8 & 15 & 9.4 & 0 & 0.0 \\
\hline Residents & 11 & 6.9 & 5 & 3.1 & 9 & 5.6 & 5 & 3.1 & 10 & 6.3 & 0 & 0.0 \\
\hline Tourists & 15 & 9.4 & 14 & 8.8 & 16 & 10.0 & 17 & 10.6 & 18 & 11.3 & 0 & 0.0 \\
\hline Students & 9 & 5.6 & 9 & 5.6 & 15 & 9.4 & 15 & 9.4 & 14 & 8.8 & 0 & $\overline{0.0}$ \\
\hline Total & 91 & 56.9 & 88 & 55.0 & 110 & 68.8 & 119 & 74.4 & 119 & 74.4 & $\mathbf{0}$ & $\overline{0.0}$ \\
\hline
\end{tabular}

Table 5 shows that 129 out of 160 or $80.66 \%$ of the total respondents are willing to pay for the entrance fee of the eco-tourism park which indicated that majority of the respondents will pay for the services that they will enjoy in the eco-tourism park. Entrance fee are utilized for the improvement of the eco-tourism park and allocated for the allowance of the tour guides [21]. Likewise, 153 or $95.6 \%$ of the respondents are willing to pay for the conservation of the eco-tourism park.

Table - 5. Distribution of Responses on the Willingness to Pay for the Entrance Fee and Conservation of Ibajay Mangrove EcoTourism Park

\begin{tabular}{|l|c|c|c|c|c|c|c|c|}
\hline \multirow{3}{*}{ Respondents } & \multicolumn{4}{|c|}{ Entrance Fee } & \multicolumn{4}{c|}{ Conservation of the Eco-Tourism } \\
\cline { 2 - 11 } & \multicolumn{2}{|c|}{ Yes } & \multicolumn{2}{|c|}{ No } & \multicolumn{2}{c|}{ Yes } & \multicolumn{2}{c|}{ No } \\
\cline { 2 - 10 } & $\mathrm{f}$ & $\%$ & $\mathrm{f}$ & $\%$ & $\mathrm{f}$ & $\%$ & $\mathrm{f}$ & $\%$ \\
\hline Businessmen & 15 & 9.38 & 5 & 3.12 & 15 & 9.40 & 5 & 3.1 \\
\hline Educators & 15 & 9.38 & 5 & 3.12 & 18 & 11.3 & 2 & 1.3 \\
\hline Industrial Partners & 17 & 10.63 & 3 & 1.87 & 20 & 12.5 & 0 & 0.0 \\
\hline LGU Personnel & 13 & 8.13 & 7 & 4.37 & 20 & 12.5 & 0 & 0.0 \\
\hline Researchers & 16 & 10.00 & 4 & 2.50 & 20 & 12.5 & 0 & 0.0 \\
\hline Residents & 17 & 10.63 & 3 & 1.87 & 20 & 12.5 & 0 & 0.0 \\
\hline Students & 17 & 10.63 & 3 & 1.87 & 20 & 12.5 & 0 & 0.0 \\
\hline Tourists & 19 & 11.88 & 1 & 0.62 & 20 & 12.5 & 0 & 0.0 \\
\hline Total & $\mathbf{1 2 9}$ & $\mathbf{8 0 . 6 6}$ & $\mathbf{3 1}$ & $\mathbf{1 9 . 4 1}$ & $\mathbf{1 5 3}$ & $\mathbf{9 5 . 6}$ & $\mathbf{7}$ & $\mathbf{4 . 4}$ \\
\hline
\end{tabular}

Table 6 shows the average amount the respondents are willing to pay for the entrance fee and conservation fee of Ibajay Mangrove Eco-Tourism Park. The respondents are willing to pay for an average of $\mathrm{P} 38.75$ per visit to the ecotourism park and are willing to pay for an average of $\mathrm{P}$ 116.88 per month for the conservation of the eco-tourism park. The average amount which is $\mathrm{P} 38.75$ is higher than $\mathrm{P}$ 20.00, the present entrance fee of the eco-tourism park. Among the respondents, businessmen are willing to pay higher for an average of P 75.00 for the entrance fee and industrial partners are willing to pay as much as P 142.00 per month for the conservation fee.

Entrance fee at Tambaliza Eco-Park and Resort at Concepcion, Iloilo is twenty pesos (P20.00) for the whole day eco-tours at the park. Visiting the park at twenty pesos (P20.00) is one better way to stimulate the conservation of the area and contribute to the creation of an economy to the local communities as well as to the municipalities [15]. 
Table - 6. Average Amount the Respondents are Willing to Pay for the Entrance Fee and Conservation Fee of Ibajay Mangrove Eco-Tourism Park

\begin{tabular}{|l|l|l|}
\hline Respondents & $\begin{array}{l}\text { Entrance } \\
\text { Fee/Visit }\end{array}$ & $\begin{array}{l}\text { Conservation of } \\
\text { Eco-Tourism } \\
\text { Park/Month }\end{array}$ \\
\hline Businessmen & P 75.00 & P 138.00 \\
\hline Educators & P 50.00 & P 100.00 \\
\hline Industrial Partners & P 50.00 & P 142.00 \\
\hline LGU Personnel & P 20.00 & P 100.00 \\
\hline Researchers & P 25.00 & P 127.00 \\
\hline Residents & P 20.00 & P 100.00 \\
\hline Students & P 20.00 & P 100.00 \\
\hline Tourists & P 50.00 & P 128.00 \\
\hline Average amount & P 38.75 & P 116. 88 \\
\hline
\end{tabular}

\section{CONCLUSION}

Based from the result of the study, the following conclusions were drawn:

1. Ninety-five percent (95\%) of the respondents are aware of the ecological and economic importance of Ibajay Mangrove Eco-Tourism Park and only eight percent (8\%) are not aware of its importance. Almost all respondents are now recognizing the ecological and economic benefits of mangrove ecosystems.

2. Maintaining the ecological balance of nature topped among the ecological importance of the eco-tourism park with $95.6 \%$, followed by foraging and living places for wildlife with $67.5 \%$. Other ecological values include recreational undertakings, interactive classroom for outdoor teachings, venue for school activities, and venue for spiritual activities. Mangrove ecosystems are unique habitat which provides direct or indirect ecological benefits to both flora and fauna.

3. Among the economic importance of the eco-tourism park, $74.4 \%$ of respondents identified both brings financial incentives to the community and served as sightseeing route of eco-tours. Both organizations, the BugtongBato Fisherfolk Association and Naisud Mangrove Aquatic Organization are benefited from $80 \%$ share of the income from the eco-tourism park. The eco-tourisms are increasing, providing source of income to the community and the Local Government Unit. Other economic importance include the following: source of food resources, source of livelihood to the locals, and source of raw materials like nipa, charcoal, firewood, fruit and sap.

4.Eighty point sixty-six percent $(80.66 \%)$ of the total respondents are willing to pay for the entrance fee of the eco-tourism park which indicated that majority of the respondents will pay for the services that they will enjoy in the eco-tourism park. Likewise, $95.6 \%$ of the respondents are willing to pay for the conservation of the eco-tourism park.

5. The average amount for the respondent are willing to pay for the entrance fee is $\mathrm{P} 38.75$ is higher than the present entrance fee which is $\mathrm{P} 20.00$. The respondents are also willing to pay for an average of $\mathrm{P} 116.88$ per month for the conservation of the eco-tourism park. Among the respondents, businessmen are willing to pay higher for an average of $\mathrm{P} 75.00$ for the entrance fee and industrial partners are willing to pay as much as P 142.00 per month for the conservation fee of the eco-tourism park.

\section{REFERENCES}

[1] Ababio, D.K.A \& Twerefou, D.K. (2012). An economic valuation of the Kakum National Park: an individual travel cost approach, African Journal of Environmental Science and Technology Vol. 6(4), pp. 199-207.

[2] Arin, T. and Kramer, R.A. (2002) Divers' willingness to pay to visit marine sanctuaries: an exploratory study: ocean and coastal management. Retrieved November 12, 2013 from http://www.nicholas.duke.edu/people/faculty/kramer/Ar in_Kramer_Divers_WTP_OCM_2002.pdf.

[3] Bann, C. (1998). The economic valuation of mangroves: a manual for researchers. Retrieved November 12, 2013 fromhttp://www.unepscs.org/Economic_Valuation_Trai ning_Materials/06\%20Readings\%20on\%20Economic\% 20Valuation\%20of\%20Coastal\%20Habitats/09Manual-Economic-Valuation-Mangroves.pdf

[4] Burgos, N. P. Jr. (2010). An amazing walk in a (mangrove) park, Philippine Daily Inquirer. Retrieved January 11, $2013 \quad$ from http://www.inquirer.net/specialreports/theenvironmentr eport/view.php?db=1\&article=20100723-282807.

[5] Cabahug, D.M. (2002). Community-based mangrove rehabilitation and eco-tourism development and management in the Red Sea Coast, Egypt. Retrieve January 17, 2013 from http://www.fao.org/3/aae213e.pdf.

[6] De Groot R.S., Wilson M.A. \& Boumans R.M.J. (2002) A typology for the classification, description and valuation of ecosystem functions, goods and services, Ecological economics, 41(3), 393-408. Retrieved December 16, 2013 from http://www.sciencedirect.com/science/article/pii/S0921 800902000897.

[7] Dehghani, M., Farshchi, P. , Danekar, A., Karami, M. and Aleshikh, A. (2010) Recreation value of hara biosphere reserve using willingness-to-pay method. Retrieved November 12, 2013, from http://www.bioline.org.br/pdf?er10030.

[8] Farber, S., Costanza, R. \& Wilson, M (2002) Economic and ecological concepts for valuing ecosystem services, Ecological economics, 41(3), 375-392. Retrieved December 16, 2013 from http://www.sciencedirect.com/science/article/pii/S0921 800902000897

[9] Feller, I. \& Sitnik, M. (1996) Mangrove ecology: a field manual focused on biocomplexity on mangrove ecosystems. Retrieved December 11, 2011 from http://www.reefball.com/reefballcoalition/mangrovestuf f/Manual\%20(2).pdf.

[10]Hoang Tri, N. (2007). Economic valuation of mangrove ecosystems. Retrieved December 12, 2013 from 
http://www.unepscs.org/Mangrove-Training/12-

Economic-Valuation-Mangrove-Ecosystems.pdf.

[11]IUCN. (2007). Environmental and socio economic value of mangroves in tsunami affected areas. Retrieved December $\quad 11, \quad 2013$ from http://cmsdata.iucn.org/downloads/sri_lanka_socioecon omic_value_report.pdf.

[12]IUCN. (2007). Valuing coastal ecosystems. Retrieved December $11, \quad 2013$ from http://earthmind.net/marine/docs/valuing-coastalecosystems.pdf.

[13]Kairo, J.G., Dahdouh-Guebas, Gwada P.O., Ochieng, C. \& Koedam, N. (2002) Regeneration status of mangrove forests in mida creek, kenya: a compromised or secured future, AMBIO: A Journal of the Human Environment. Retrieved December 2, 2013 from http://pinnacle.allenpress.com/doi/abs/10.1579/00447447-31.7.562?.journalCode=ambi.

[14]King, D.M. \& Mazzotta, M.J. (2000) Contingent valuation method. Retrieve December 16, 2013 from http://www.ecosystemvaluation.org/contingent_valuatio n.htm.

[15]Marin, B.G. (2011) Tambaliza eco-park and resort. Retrieve January 17, 2013 from http://pasapinoy.com/tag/bombette-g-marin/html.

[16]Mendoza, E., Jr. (2010) Calajao mangrove eco-park. Retrieve January 31, 20213 from http://www.gigsilonggo.com/culajao-mangrove-ecopark-roxas-city-capiz.html.

[17]Primavera JH, Sadaba, RB Lebata, MJHL \& Altamirano, JP. (2004). Handbook of mangroves in the Philippines - Panay. SEAFDEC, Iloilo, Philippines.

[18]Primavera, J.H., Savaris, J.P., Bajoyo, B.E., Coching, J.D., Curnick, D.J., \& et al (2012) Manual on community-based mangrove rehabilitation, Zoological Society of London. Retrieve February 2, 2013 from http://www.zsl.org/sites/default/files/media/201405/Manual\%20on\%20CommunityBased\%20Mangrove\%20Rehabilitation.pdf.

[19]Rosales, R., Kallesoe, M., Gerrard, P., Muangchanh, P., Phomtavong, S., \& Khamsomphou, S. (2005) Balancing the returns to catchment management: the economic value of conserving natural forests in Sekong, Lao PDR. Retrieved January 11, 2013 from https://www.cbd.int/financial/values/laoeconomicreturn-iucn.pdf.

[20]Savaris, J.P., Joven R.V., Golbeque, R.L., Bajoyo, B.E., Borci, J.E., \& Primavera, J.H. (2011) Conceptual framework in organizing communities for effective mangrove management. Retrieved January 28, 2013 from http://www.seafdec.or.th/wsfc2010/CZAPWSFC\%20Conference\%20Proceedings/Speed\%20sessi on $\% 201 /$ Josephine $\% 20$ Savaris\%20CZAPWSFC\%202010.pdf.

[21]Villorente, M.S. (2010) Ibajay's ASU-CHARRM \& centuries-old mangroves: A response to employment opportunities and ecological protection. Retrieved
January 12, 2013 from http://madyaaspen.blogspot.com/2010/05/ibajays-asucharrm-centuries-old.html.

[22]Walters, B.B. (2003) Local mangrove forest management: successful conservation for efficient resources \& exploitation. Retrieved February 11, 2013 from http://www.fao.org/docrep/ARTICLE/WFC/XII/0032C1.HTM\#fn1.

[23]http://www.bfar.da.gov.ph/pages/Legislation/IRR_8550. html. Retrieved December 11, 2013.

[24]http://www.nature.org/media/oceansandcoasts/mangrov es-for-coastal-defence.pdf. Retrieved November 29, 2013.

[25]http://www.aims.gov.au/docs/projectnet/mangrovesuses.html. Retrieved December 12, 2013.

\section{BIOGRAPHY}

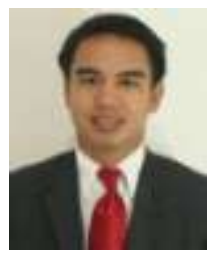

The author is a science faculty of the School of Arts and Sciences, Carlos Hilado Memorial State College, Talisay City, Negros Occidental, Philippines. His researches are focused on environment and natural product chemistry. 